\title{
FERTIGATION OF SUNFLOWER CROPS USING LANDFILL LEACHATE ${ }^{1}$
}

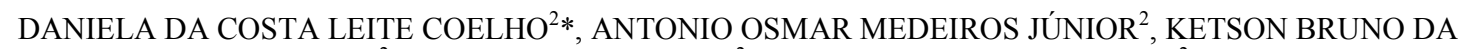 \\ SILVA $^{2}$, NILDO DA SILVA DIAS ${ }^{2}$, RAFAEL OLIVEIRA BATISTA ${ }^{2}$
}

\begin{abstract}
The use of landfill leachate (LL) to produce biomass for energy and biofuel purposes is an alternative that minimizes environmental degradation. In this context, the objective of this work was to evaluate the effect of using different rates of LL in the fertigation of sunflower (Helianthus annuus L.) crops. The experiment was conducted in a randomized block design with five treatments and four replications-20 experimental plots. The treatments consisted of control with 100\% water from the water supply (WWS) ( $\left.\mathrm{T}_{1}\right)$; $80 \% \mathrm{WWS}+20 \% \mathrm{LL}\left(\mathrm{T}_{2}\right) ; 60 \% \mathrm{WWS}+40 \% \mathrm{LL}\left(\mathrm{T}_{3}\right) ; 40 \% \mathrm{WWS}+60 \% \mathrm{LL}\left(\mathrm{T}_{4}\right) ;$ and $20 \% \mathrm{WWS}+80 \% \mathrm{LL}$ $\left(\mathrm{T}_{5}\right)$. The sunflower crops were grown in a eutrophic Red-Yellow Argisol for 81 days, in Mossoró RN, Brazil. The plant characteristics evaluated - plant height, number of leaves, steam diameter and capitulum diameterwas determined. All variables evaluated presented statistical differences between treatments. In general, plants in the treatment $60 \% \mathrm{WWS}+40 \%$ LL presented better performance regarding the characteristics evaluated.
\end{abstract}

Keywords: Helianthus annuus L.. Urban wastewater. Biomass. Biofuel.

\section{PRODUÇÃO DE GIRASSOL FERTIRRIGADO COM PERCOLADO DE ATERRO SANITÁRIO}

RESUMO - O uso do percolado de aterro sanitário (PATS) na produção de biomassa para fins energético e biocombustível é uma alternativa que minimiza a degradação ambiental. Neste contexto, objetivou-se neste trabalho, analisar o efeito da aplicação de distintas proporções de percolado de aterros sanitários no cultivo de girassol (Helianthus annuus L.). O experimento foi conduzido com delineamento em blocos casualizados, com cinco tratamentos $\mathrm{T}_{1}-100 \%$ de água da rede de abastecimento - AA (Testemunha); $\mathrm{T}_{2}-80 \%$ de AA e $20 \%$ de PATS; $\mathrm{T}_{3}-60 \%$ de AA e $40 \%$ de PATS; $\mathrm{T}_{4}-40 \%$ de AA e $60 \%$ de PATS; e, $\mathrm{T}_{5}-20 \%$ de AA e $80 \%$ de PATS, e quatro repetições, totalizando 20 parcelas experimentais. O girassol foi cultivado em ARGISSOLO Vermelho - Amarelo eutrófico, durante 81 dias em Mossoró/RN. Durante o ciclo do girassol foram determinadas as características vegetativas altura de planta (AP), número de folhas (NF), diâmetro do caule (DCaule) e do capítulo (DCapítulo). Comprovou-se que para todas as variáveis estudadas houve diferença estatística entre os tratamentos. Em geral, o tratamento $60 \%$ de AA e $40 \%$ de PATS apresentou melhor desempenho com relação às características vegetativas do girassol.

Palavras-chave: Helianthus annuus L.. Resíduo líquido urbano. Biomassa. Biocombustível.

\footnotetext{
${ }^{*}$ Corresponding author

${ }^{1}$ Received for publication in $09 / 27 / 2016$; accepted in 10/23/2017.

Paper extracted from first author's doctoral dissertation.

${ }^{2}$ Department of Engineering and Environmental Sciences, Universidade Federal Rural do Semi-Árido, Mossoró, RN, Brazil; daniela.coelho@ufersa.edu.br - ORCID: 0000-0001-9182-3675, j.osmarx@hotmail.com - ORCID: 0000-0003-1324-5990, ketsonbruno@hotmail.com - ORCID: 0000-0002-2553-0513, nildo@ufersa.edu.br - ORCID: 0000-0002-1276-5444,
} rafaelbatista@ufersa.edu.br - ORCID: 0000-0002-3083-6808. 


\section{INTRODUCTION}

The disposal of urban solid residues in landfills cause degradation of their organic material, and generation of a liquid of dark color and unpleasant odor that is highly polluting and has high organic and inorganic load, toxic and recalcitrant substances, commonly called landfill leachate (LL) (MATOS et al., 2013; BEDIN, 2011; MENDONÇA, 2010; LAUERMANN, 2007; BRENTANO, 2006).

LL has a high pollution potential, thus, the lack of treatment or inadequate treatment and management of such liquid waste can cause serious environmental impacts, such as pollution of soil, and surface and underground water resources (MATOS et al., 2013).

The use of LL as fertigation of agricultural crops favors the expansion of the irrigated area, makes it possible to increase crop yield and quality, improves the physical, chemical, and biological characteristics of the soil, and improves environmental and public health, when used together with appropriate agronomic management practices (CHEVREMONT et al., 2013; DUTRA, 2013; LO MONACO et al., 2009; HESPANHOL, 2008).

The volume of LL to be applied in crops must be based on the recommended nutrient rates and estimated water requirement for the crops (LO MONACO et al., 2009), i.e., water must be added to the LL to supply the plant need for nutrients and water.

Sunflower (Helianthus annuus L.) is an annual dicotyledonous plant from the Asteraceae family. The name Helianthus refers to the moving of the flower in relation to the sun, a phenomenon known as heliotropism (SOUSA et al., 2012; COSTA, 2012; OLIVEIRA et al., 2005; CASTRO; FARIAS, 2005). It is a remarkable plant because of its economic potential, since all parts of this plant can be commercially used (SOUZA et al., 2013; LIRA et al., 2011; CARRÃO-PANIZZI; MANDARINO, 2005).

Sunflower can be used as human and animal food, as an ornamental plant, and as raw material for biofuel production (LIRA et al., 2011; GAZZOLA et al., 2012). In Brazil, this crop is among the main crop species with potential for renewable energy production (SILVA et al., 2013).

Sunflower is a source of a high-quality oil that is used in the biofuel production. This biofuel does not contain petroleum products; thus, it reduces emissions of pollutants into the atmosphere. According to studies conducted in São Paulo, Brazil, the biofuel originated from sunflower is viable, without the need of adaptation of engines (LIRA et al., 2011), and has technical and environmental feasibility (BONACIN et al., 2009).

Lopes et al. (2009) emphasized the productive potential of renewable energy production of this crop, and its importance as an alternative for producers using crop rotation systems.

Researches on irrigation in sunflower crops showed the importance of water availability for the development of this plant species (FREITAS et al., 2012; SILVA et al., 2007).

Primary macronutrients, especially nitrogen, phosphorus and potassium are essential elements to nutrition and fertilization of sunflower. Nitrogen is the most limiting nutrient to sunflower production and the most absorbed and exported by its grains, followed by potassium, which is involved in the plant's resistance to drought and diseases, and phosphorus, which directly affect root growth and grain filling. Regarding the micronutrients, boron application is important because its deficiency causes the sunflower leaves and capitula to undergo several deformations (GAZZOLA et al., 2012; CÂMARA, 2003; CASTRO et al., 1997).

In this context, the objective of this work was to evaluate the effect of using different rates of LL in the fertigation of sunflower (Helianthus annuus L.) crops, and verify the feasibility of this practice for a proper disposal of this leachate in the soil, focused on the production of biomass for energy purposes.

\section{MATERIAL AND METHODS}

The experiment was conducted in an area of the Zoobotanical Park of the Federal Rural University of Semiarid (UFERSA), Mossoró RN, Brazil ( $5^{\circ} 12^{\prime} 31^{\prime \prime S}, 37^{\circ} 19^{\prime} 07^{\prime \prime} \mathrm{W}$, and altitude of $\left.27 \mathrm{~m}\right)$.

The region has a BSwh, dry and very hot climate, according to the classification of Köppen, with a rainy season in summer to autumn, irregular precipitation, annual average precipitation of $673.9 \mathrm{~mm}$, average temperature of $27^{\circ} \mathrm{C}$, and average air relative humidity of $68.9 \%$ (ALVARES et al., 2013).

According to the analyses performed using the guidelines established by the Brazilian Soil Classification System of the Brazilian Agricultural Research Corporation (EMBRAPA, 2013), the soil of the area is a eutrophic Red-Yellow Argisol, with a practically impermeable layer from the depth of $0.40 \mathrm{~m}$. The physical and chemical characteristics of the soil of the experimental area, before the application of landfill leachate (LL), was determined according to the methodology described by Donagema et al. (2011) and Embrapa (SILVA, 2009) (Tables 1 and 2). 
D. C. L. COELHO et al.

Table 1. Physical characteristics of the soil used in the experiment before the application of landfill leachate.

\begin{tabular}{cccccc}
\hline Layer $(\mathrm{m})$ & Soil density & Sand & Silt & Clay & $\begin{array}{c}\text { Gravimetric } \\
\text { moisture } \\
\%\end{array}$ \\
\hline $0.00-0.20$ & 1.81 & 660 & 230 & 100 & 12.10 \\
$0.20-0.40$ & 1.63 & 620 & 130 & 250 & 8.66 \\
\hline
\end{tabular}

Table 2. Chemical characteristics of the soil used in the experiment before the application of landfill leachate.

\begin{tabular}{|c|c|c|c|c|c|c|c|}
\hline \multirow{2}{*}{ Characteristics } & & \multicolumn{2}{|c|}{ Layer (m) } & \multirow{2}{*}{ Characteristics } & & \multicolumn{2}{|c|}{ Layer (m) } \\
\hline & & $0.00-0.20$ & $0.20-0.40$ & & & $0.00-0.20$ & $0.20-0.40$ \\
\hline $\mathrm{pH}$ & & 7.47 & 6.99 & \multirow{2}{*}{$\mathrm{Fe}$} & & \multirow{2}{*}{25.93} & \multirow{2}{*}{30.02} \\
\hline $\mathrm{EC}_{1: 2,5}$ & $\mathrm{dS} \mathrm{m}^{-1}$ & 0.2 & 0.09 & & & & \\
\hline $\mathrm{OM}$ & dag $\mathrm{kg}^{-1}$ & 0.69 & 0.55 & \multirow{2}{*}{$\mathrm{Mn}$} & & \multirow{2}{*}{107.4} & \multirow{2}{*}{75.5} \\
\hline $\mathrm{N}$ & $\mathrm{g} \mathrm{kg}^{-1}$ & 0.36 & 0.4 & & & & \\
\hline $\mathrm{P}$ & & 12.18 & 5.97 & \multirow{2}{*}{$\mathrm{Cu}$} & & \multirow{2}{*}{0.17} & \multirow{2}{*}{0.18} \\
\hline $\mathrm{K}^{+}$ & $\mathrm{mg} \mathrm{dm}-3$ & 145.7 & 194.31 & & & & \\
\hline $\mathrm{Na}^{+}$ & & 78.52 & 71.5 & \multirow{2}{*}{$\mathrm{Zn}$} & & \multirow{2}{*}{1.94} & \multirow{2}{*}{0.65} \\
\hline $\mathrm{Ca}^{2+}$ & & 2.54 & 2.32 & & & & \\
\hline $\mathrm{Mg}^{2+}$ & & 1.53 & 1.74 & \multirow{3}{*}{$\mathrm{Ni}$} & $\mathrm{mg} \mathrm{dm} \mathrm{m}^{-3}$ & \multirow{3}{*}{0.05} & \multirow{3}{*}{0.06} \\
\hline $\mathrm{Al}^{3+}$ & & 0.00 & 0.00 & & & & \\
\hline $\mathrm{H}+\mathrm{Al}$ & $\mathrm{cmol}_{\mathrm{c}} \mathrm{dm}^{-3}$ & 0.35 & 0.37 & & & & \\
\hline SB & & 4.77 & 4.86 & \multirow{3}{*}{$\mathrm{Pb}$} & & \multirow{3}{*}{0.17} & \multirow{3}{*}{0.15} \\
\hline CEC & & 5.12 & 5.24 & & & & \\
\hline $\mathrm{T}$ & & 4.77 & 4.86 & & & & \\
\hline $\mathrm{V}$ & & 93.47 & 92.84 & \multirow{3}{*}{$\mathrm{Cd}$} & & \multirow{3}{*}{0.01} & \multirow{3}{*}{0.00} \\
\hline M & $\%$ & 0.00 & 0.00 & & & & \\
\hline PES & & 7.13 & 6.52 & & & & \\
\hline
\end{tabular}

The experiment was developed from June to September 2015. The LL from the landfill of Mossoró RN, Brazil was taken to the experimental area of the UFERSA in a 1,000-L plastic container. The water from the water supply used in the work was taken from the public water supplied by the Water and Sewage Company of Rio Grande do Norte (CAERN).

Water samples from the water supply and LL were collected biweekly during the study period, and their physical and chemical characteristics were analyzed according to the recommendations in the Standard Methods for the Examination of Water and Wastewater (RICE; BAIRD; CLESCERI, 2012) and Embrapa (SILVA, 2009).

The system used to apply the water from water supply (WWS) and LL consisted of a pressurized irrigation system consisting of: two $1,000-\mathrm{L}\left(1.0 \mathrm{~m}^{3}\right)$ tanks to store the WWS; two $1,000-\mathrm{L}$ tanks and one $250-\mathrm{L}\left(0.25 \mathrm{~m}^{3}\right)$ tank to store the LL; two automated motor pump $(0.5 \mathrm{cv})$ with two disc filters with $130-\mu \mathrm{m}$ openings for each application line; two main lines of polyvinyl chloride (PVC) tubes with diameter of $32 \mathrm{~mm}$, which originated a single main line that was subdivided for the plots; and twenty lateral drip irrigation lines with non-pressure compensating emitters of $1.6 \mathrm{~L} \mathrm{~h}^{-1}$ flow, spaced $0.30 \mathrm{~m}$ apart. Each lateral line was placed contouring the four plant rows of each plot (Figure 1).

The sunflower (Helianthus annuus L.) variety used was the BRS-324, which was developed by the Embrapa Soja, in partnership with the Embrapa Clima Temperado (Pelotas RS), Embrapa Cerrados (Planaltina DF), Embrapa Tabuleiros Costeiros (Aracaju SE), Embrapa Rondônia (C.E. Vilhena RO), Embrapa Meio Ambiente (Jaguariúna SP) and Embrapa Gado de Leite (Juiz de Fora MG) (CARVALHO et al., 2013). The BRS-324 seeds were launched in 2014 by the Embrapa Produtos e Mercado, Dourados MS, Brazil (CARVALHO et al., 2013).

The sunflower BRS-324 is an early cycle, open-pollinated cultivar, whose grains has high oil content, which adds value to its production. It is suitable for crops in the Brazilian states of Bahia, Goiás, Mato Grosso, Mato Grosso do Sul, Minas Gerais, Paraná, Rio Grande do Sul, Rondônia, São Paulo and Sergipe (CARVALHO et al., 2013). 


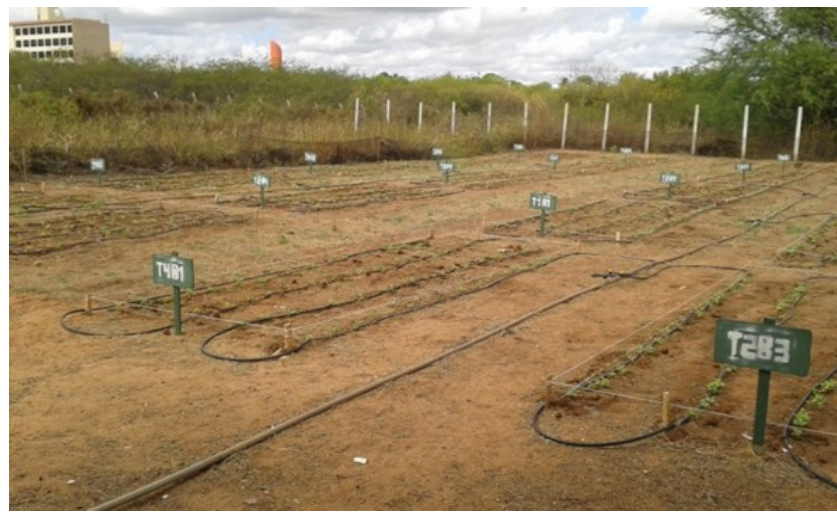

Figure 1. Experimental plots with sunflower crops and the irrigation line arrangement.

The experiment was conducted in a randomized block design, with twenty experimental plots, five treatments, and four replications. The treatments were based on studies developed by Andrade Filho (2016) and Costa (2012), and consisted of control with $100 \%$ WWS $\left(\mathrm{T}_{1}\right) ; 80 \%$ WWS + 20\% LL ( $\left.\mathrm{T}_{2}\right) ; 60 \% \mathrm{WWS}+40 \% \mathrm{LL}\left(\mathrm{T}_{3}\right) ;$ $40 \% \mathrm{WWS}+60 \% \mathrm{LL}\left(\mathrm{T}_{4}\right)$; and $20 \% \mathrm{WWS}+80 \%$ $\mathrm{LL}\left(\mathrm{T}_{5}\right)$

The experimental plots had area of $2.0 \times 5.0$ $\mathrm{m}\left(10 \mathrm{~m}^{2}\right)$, with spacing of $2.0 \mathrm{~m}$ between blocks and $1.0 \mathrm{~m}$ between plots of the same block.

The plots subjected to T1 (control with WWS) received no planting fertilization; however, this area had received some fertilization in a previous experiment (ANDRADE FILHO, 2016). The plots subjected to the other treatments received only the nutrients present in the LL during the experimental period.

The water requirement of sunflower was estimated based on the soil water balance and crop evapotranspiration according to the methodology described by the FAO (Food and Agriculture Organization of the United Nations) using the Penman-Monteith equation (ALLEN et al., 2006) (Equation 1).

$$
\mathrm{ET}_{0}=\frac{0.408 \Delta(\mathrm{Rn}-\mathrm{G})+\gamma \frac{900}{\mathrm{~T}+273} \mathrm{U}_{2}\left(\mathrm{e}_{\mathrm{s}}-\mathrm{e}_{\mathrm{a}}\right)}{\Delta+\gamma\left(1+0.34 \mathrm{U}_{2}\right)}
$$

wherein:

ETo is the reference evapotranspiration $\left(\mathrm{mm} \mathrm{day}^{-1}\right)$; $\mathrm{Rn}$ is the surface radiation $\left(\mathrm{MJ} \mathrm{m}^{-2} \mathrm{day}^{-1}\right)$; $\mathrm{G}$ is the soil heat flow $\left(\mathrm{MJ} \mathrm{m}^{-2}\right.$ day $\left.^{-1}\right)$;

$\mathrm{T}$ is the air temperature at $2 \mathrm{~m}$ height $\left({ }^{\circ} \mathrm{C}\right)$; $\mathrm{U}_{2}$ is the wind speed at $2 \mathrm{~m}$ height $\left(\mathrm{m} \mathrm{s}^{-1}\right)$; $\mathrm{e}_{\mathrm{s}}$ is the vapor saturation pressure $(\mathrm{kPa})$; $\mathrm{e}_{\mathrm{a}}$ is the current air vapor pressure $(\mathrm{kPa})$; $\left(\mathrm{e}_{\mathrm{s}}-\mathrm{e}_{\mathrm{a}}\right)$ is the vapor pressure deficit $(\mathrm{kPa})$; $\mathrm{D}$ is the curve slope of the vapor saturation pressure $\left(\mathrm{kPa}{ }^{\circ} \mathrm{C}^{-1}\right)$; and, $\mathrm{g}$ is the psychrometric constant $\left(\mathrm{kPa}^{\circ} \mathrm{C}^{-1}\right)$.

The meteorological data needed to estimate the reference evapotranspiration (ETo) - wind speed, relative air humidity, insolation, solar radiation, precipitation, and temperature-were obtained from a meteorological station installed in the UFERSA, Mossoró campus.

The crop evapotranspiration (ETc) was estimated using the crop coefficient $(\mathrm{Kc})$ obtained by Cavalcante Júnior (2011) in studies in Apodi RN, and used by Costa (2012) in experiments with sunflower in that region.

According to Cavalcante Júnior (2011), the Kc were $0.52,0.70,0.98$, and 0.81 for the sunflower development stages I, II, III, and IV, respectively. These Kc were similar to the ones recommended in the Manual 56 of the FAO for sunflower crops.

The irrigation water depth applied intended to meet the water demand of the crop and the fertigation intended to supply the plants with the nutrients contained in the LL.

The fertigation with LL was applied on alternate days from July 24, 2015, that was 21 days after planting (DAP), 14 days after transplanting (DAT), to favor the establishment of the sunflower seedlings in the soil and prevent them from dying at the beginning of the cycle.

Irrigation with WWS was performed in parallel to the fertigation with LL during the crop cycle.

Characteristics of the sunflower crops were assessed in five evaluations with 15-day intervals - July 24, 2015 (21 DAP, 14 DAT), August 08, 2015 (36 DAP), August 23, 2015 (51 DAP), September 07, 2015 (66 DAP), and at harvesting, in September 22, 2015 (81 DAP).

The six central plants of each plot were marked to be used as samples in all evaluations, and their means were used to estimate the characteristics of each plot.

The plant height from the ground level to the capitulum insertion was measured using a scale and expressed in meters. The number of completely open leaves of each sample plant was counted. The stem base diameter (SD) was measured with a digital caliper at a height of approximately $5 \mathrm{~cm}$ from the ground, according to the methodology used by Costa (2012), and expressed in centimeters. The capitulum diameter of each sample plant was measured with a digital caliper and expressed in centimeters. 
The data of the evaluated characteristics of the sunflower plants were subjected to analysis of variance by the $\mathrm{F}$ test at $5 \%$ probability, and significant means were subjected to the Tukey's test at $5 \%$ probability, and regression analysis. Statistical analyzes were performed using the Sisvar 5.6 statistical program (FERREIRA, 2014; FERREIRA, 2011).

\section{RESULTS AND DISCUSSION}

Table 3. Analysis of variance for the variables plant height (PH), number of leaves (NL), stem diameter (SD) and capitulum diameter (CD) of sunflower plants subjected to fertigation with different rates of landfill leachate (LL).

\begin{tabular}{|c|c|c|c|c|c|}
\hline \multirow[b]{2}{*}{ Source of Variation (SV) } & \multirow[b]{2}{*}{$\begin{array}{c}\text { Degree of } \\
\text { freedom (DF) }\end{array}$} & \multicolumn{4}{|c|}{ Mean Square (MS) } \\
\hline & & $\begin{array}{l}\mathrm{PH} \\
(\mathrm{m})\end{array}$ & $\begin{array}{c}\mathrm{NL} \\
\text { (unidades) }\end{array}$ & $\begin{array}{l}\mathrm{SD} \\
(\mathrm{cm})\end{array}$ & $\begin{array}{l}\mathrm{CD} \\
(\mathrm{cm})\end{array}$ \\
\hline Treatments & 4 & $0.1381^{* *}$ & $21.6213^{* *}$ & $0.2114^{* *}$ & $5.0072^{* *}$ \\
\hline Time & 4 & $2.0652^{* *}$ & $702.5876^{* *}$ & $2.3050^{* *}$ & $458.1548^{* *}$ \\
\hline Treatments $\mathrm{x}$ Time & 16 & $0.0185^{*}$ & $5.3939^{\text {n.s. }}$ & $0.0235^{\text {n.s. }}$ & $2.2809^{* *}$ \\
\hline Block & 3 & $0.0394^{* *}$ & $7.7784^{\text {n.s. }}$ & $0.1045^{* *}$ & $3.1728^{*}$ \\
\hline Error & 72 & 0.0083 & 3.9377 & 0.0178 & 0.9963 \\
\hline Coefficient of variation (CV) $(\%)$ & - & 17.92 & 12.61 & 18.77 & 27.89 \\
\hline
\end{tabular}

Regarding the effects of the LL rates applied, the variables $\mathrm{PH}, \mathrm{NL}, \mathrm{SD}$, and $\mathrm{CD}$ presented significant statistical differences by the Tukey's test at $5 \%$ probability.

According to the regression analysis, the $\mathrm{PH}$, $\mathrm{SD}$, and $\mathrm{CD}$ were significantly affected by the
The means of the plant characteristics evaluated-plant height (PH), number of leaves (NL), stem diameter (SD) and capitulum diameter (CD) - were significant by the $\mathrm{F}$ test at $5 \%$ probability regarding the landfill leachate $(\mathrm{LL})$ rates applied (treatments) and time of application. The interaction between treatments and time of application had significant effect only on $\mathrm{PH}$ and $\mathrm{CD}$ (Table 3).

Table 4. Regression equations of characteristics of sunflower plants as a function of application of landfill leachate rates.

\begin{tabular}{lcc}
\hline Characteristics & Regression equations \\
\hline $\mathrm{PH}$ & $\mathrm{PH}=0.624390-0.038730^{* *}$ Rates & $\mathrm{R}^{2}=0.54$ \\
$\mathrm{SD}$ & $\mathrm{SD}=0.836685-0.041695^{* *}$ Rates & $\mathrm{R}^{2}=0.41$ \\
$\mathrm{CD}$ & $\mathrm{CD}=4.177840-0.199810^{* *}$ Rates & $\mathrm{R}^{2}=0.40$ \\
\hline
\end{tabular}

**and *= significant at 1 and $5 \%$ probability by the Tukeys' test, respectively.

A.

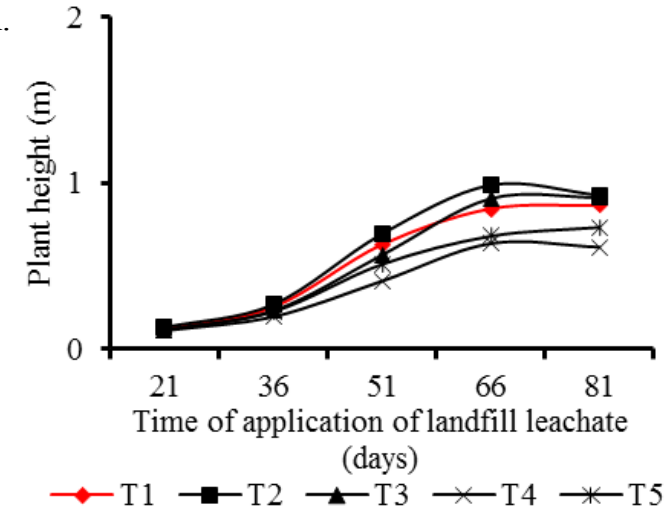

treatments (Table 4).

The treatments with the highest LL rates $\left(\mathrm{T}_{4}\right.$ and $\mathrm{T}_{5}$ ) provided no satisfactory results regarding the sunflower performance, with lower values than the control $\left(\mathrm{T}_{1}\right)$ (Figure $\left.2 \mathrm{~A}\right)$.

$\mathrm{T}_{1}=$ control with $100 \%$ water from the water supply (WWS); $\mathrm{T}_{2}=80 \% \mathrm{WWS}+20 \% \mathrm{LL} ; \mathrm{T}_{3}=60 \% \mathrm{WWS}+40 \% \mathrm{LL} ; \mathrm{T} 4=$ $40 \% \mathrm{WWS}+60 \% \mathrm{LL}\left(\mathrm{T}_{4}\right)$; and $\mathrm{T}_{5}=20 \% \mathrm{WWS}+80 \% \mathrm{LL}$. Means followed by at least one equal letter in the columns for each treatment do not differ at $5 \%$ probability by the Tukey's test.

Figure 2. Plant height (PH) of sunflower plants as a function of the time of application of landfill leachate (LL) (A), and LL rates applied as fertigation (B). 
The $\mathrm{T}_{2}$ treatment had the highest $\mathrm{PH}$ during the samplings and the highest mean at the end of the crop cycle (Figures 2A and 2B). The plants subjected to $\mathrm{LL}$ rates presented no differences at the beginning of the experiment, but presented significant differences at the end of the experiment (Figure 2A).

The mean $\mathrm{PH}$ of plants in $\mathrm{T}_{2}$ at the end of the experiment was $0.93 \mathrm{~m}$; this treatment did not differ statistically from $T_{1}$ and $T_{3} . T_{4}$ had the lowest mean $\mathrm{PH}(0.61 \mathrm{~m})$, and did not differ statistically from $\mathrm{T}_{5}$. The treatment with $40 \% \mathrm{LL}\left(\mathrm{T}_{3}\right)$ met the sunflower requirements satisfactorily; this treatment did not differ from $\mathrm{T}_{2}$ and used a higher rate of $\mathrm{LL}$, thus saving good-quality water.

The mean PH of sunflower (variety BRS-324) found by Carvalho et al. (2013) was between 1.70-1.90. The PH found in the present study were lower, however, no additional fertilization was applied, and good-quality water was saved.

The low PH with application of high rates of LL is probably due to the high concentration of salts in the LL, mainly sodium, which increases soil electrical conductivity when used in successive applications, reducing the soil quality and crop biomass production (MESQUITA, 2016; FERREIRA, 2013).

Ferreira (2013) evaluated the effects of increasing rates of wastewater on three soils (Argisol, Cambisol, and Vertisol) with

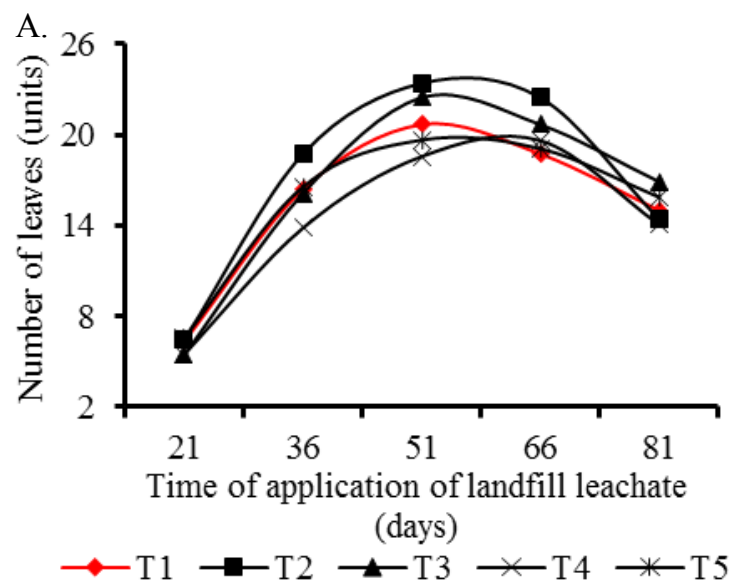

sunflower, and found maximum $\mathrm{PH}(0.55 \mathrm{~m})$ using $55.4 \mathrm{~m}^{3}$ of $\mathrm{N} \mathrm{ha}^{-1}$ on the Vertisol, and the lowest plant growth in the Argisol.

Silva (2014) found $\mathrm{PH}$ of $0.79 \mathrm{~m}$ for the sunflower variety BRS-323 grown with crude and photo-electrochemically treated leachate, and plants treated with concentrations of 25,50 and $75 \%$ with similar PH.

Mesquita (2016) evaluated soils fertigated with LL for Pennisetum purpureum grass and found non-significant effects of treatments on PH. However, Andrade Filho (2016) evaluated the effect of LL in castor bean crops under similar experimental conditions to the present study, and found the highest $\mathrm{PH}$ in plants treated with $40 \%$ WWS $+60 \% \mathrm{LL}$, at the end of the experimental period, and the lowest $\mathrm{PH}$ in plants treated with $20 \%$ WWS $+80 \%$ LL. These results differ from those found in the present study, in which the plants in $\mathrm{T}_{2}$ (20\% LL) presented the highest PH.

The NL increased with the LL rates; plants in $\mathrm{T}_{2}$ and $\mathrm{T}_{3}$ had higher NL than the ones in the control $\left(\mathrm{T}_{1}\right)$ (Figure 3A). However, treatments with the highest LL rates $\left(T_{4}\right.$ and $\left.T_{5}\right)$ caused a decrease in NL.

Plants in $T_{2}$ had the highest NL; this treatment presented no statistic difference from $T_{1}$, $\mathrm{T}_{3}$ and $\mathrm{T}_{5}$; and $\mathrm{T}_{5}$ did not differ statistically from $\mathrm{T}_{1}$ and $\mathrm{T}_{4}$ (Figure $3 \mathrm{~B}$ ).

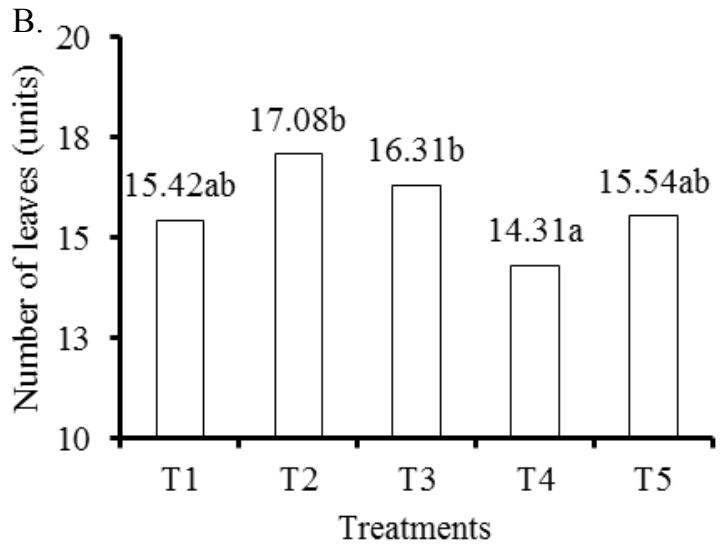

$\mathrm{T}_{1}=$ control with $100 \%$ water from the water supply (WWS); $\mathrm{T}_{2}=80 \% \mathrm{WWS}+20 \% \mathrm{LL} ; \mathrm{T}_{3}=60 \% \mathrm{WWS}+40 \%$ $\mathrm{LL} ; \mathrm{T} 4=40 \% \mathrm{WWS}+60 \% \mathrm{LL}\left(\mathrm{T}_{4}\right)$; and $\mathrm{T}_{5}=20 \% \mathrm{WWS}+80 \% \mathrm{LL}$. Means followed by at least one equal letter in the columns for each treatment do not differ at $5 \%$ probability by the Tukey's test.

Figure 3. Number of leaves (NL) of sunflower plants as a function of time of application of landfill leachate (LL) (A), and LL rates applied in the fertigation (B).

The NL found were lower than the ones found in the literature-20 to 40 leaves per plant for this species (CASTRO et al., 1997; COSTA, 2012; CALEGARI et al., 1993). The NL of plants in $\mathrm{T}_{2}$ were close to these values.

Costa (2012) evaluated the application of different rates of domestic wastewater in soils with sunflower crops and, similarly to the preset work, found a slight increase in NL with increasing wastewater rates.

Different results were found by Andrade Filho (2016), who evaluated LL in soils with crops of oleaginous plants and found the highest NL in 
plants treated with $40 \%$ WWS $+60 \%$ LL, in all samplings carried out over the study period.

The SD differed statistically between treatments over the experimental period (Figure 4A). The treatments with the lowest LL rates $\left(\mathrm{T}_{2}\right.$ and $\left.\mathrm{T}_{3}\right)$

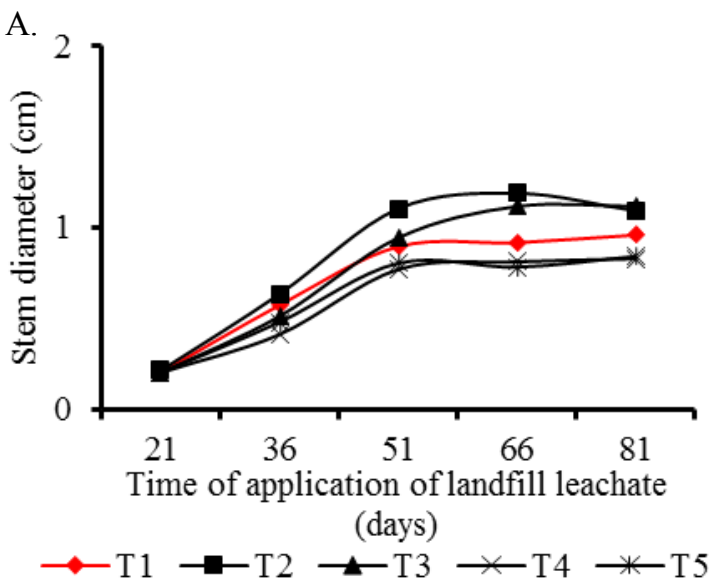

had plants with larger $\mathrm{SD}$ than the ones in $\mathrm{T}_{1}$ (control). The treatments with the highest LL rates $\left(\mathrm{T}_{4}\right.$ and $\mathrm{T}_{5}$ ) had plants with lower $\mathrm{SD}$, compared to the other treatments, including $\mathrm{T}_{1}$.

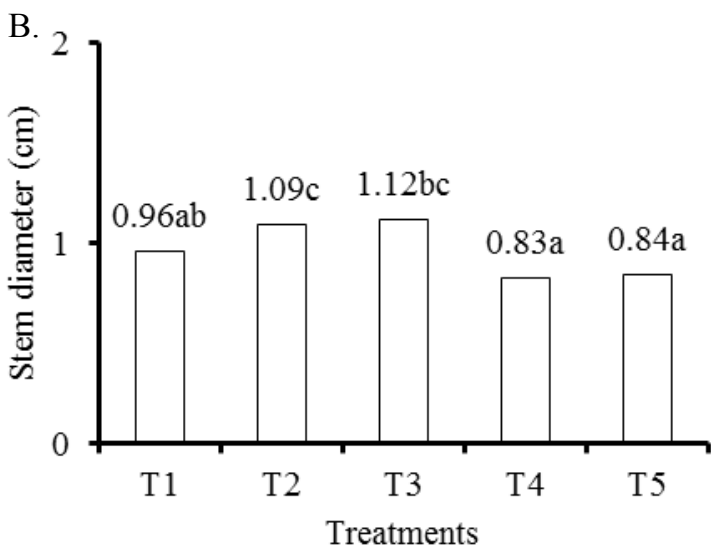

$\mathrm{T}_{1}=$ control with $100 \%$ water from the water supply (WWS); $\mathrm{T}_{2}=80 \% \mathrm{WWS}+20 \% \mathrm{LL} ; \mathrm{T}_{3}=60 \% \mathrm{WWS}+40 \%$ $\mathrm{LL} ; \mathrm{T} 4=40 \% \mathrm{WWS}+60 \% \mathrm{LL}\left(\mathrm{T}_{4}\right)$; and $\mathrm{T}_{5}=20 \% \mathrm{WWS}+80 \% \mathrm{LL}$. Means followed by at least one equal letter in the columns for each treatment do not differ at $5 \%$ probability by the Tukey's test.

Figure 4. Stem diameter (SD) of sunflower plants as a function of time of application of landfill leachate (LL) (A), and LL rates applied in the fertigation (B).

Plants in $\mathrm{T}_{3}$ had the largest mean $\mathrm{SD}$ $(1.12 \mathrm{~cm})$ at the end of the crop cycle (Figure $4 \mathrm{~B}$ ), but this treatment did not differ statistically from $\mathrm{T}_{1}$ and $\mathrm{T}_{2}$. Plants in $\mathrm{T}_{1}$ did not differ statistically from the ones in $\mathrm{T}_{4}$ and $\mathrm{T}_{5}$.

Andrade Filho (2016) found different results;

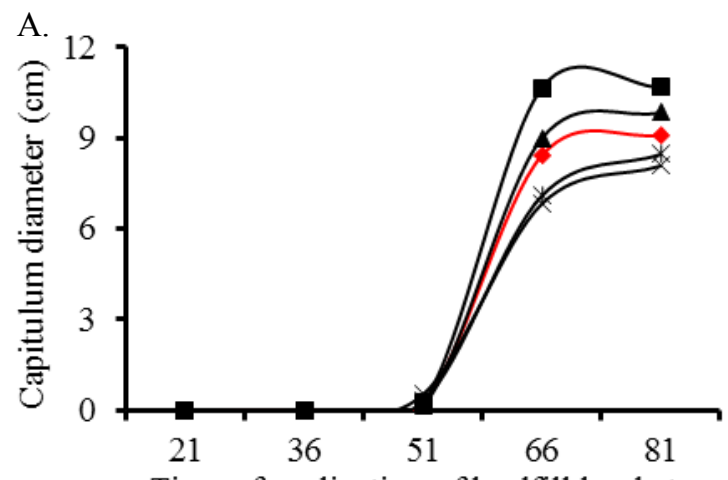

Time of application of landfill leachate

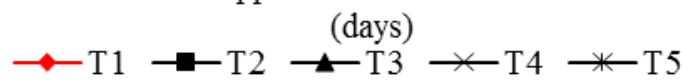

the development of castor bean plants treated with $80 \%$ LL was affected negatively, presenting the smallest SD, probably due to the toxic effect of LL in this crop species.

The largest $\mathrm{CD}$ were found in plants in $\mathrm{T}_{2}$, followed by the ones in $\mathrm{T}_{3}$ (Figure $5 \mathrm{~A}$ ).

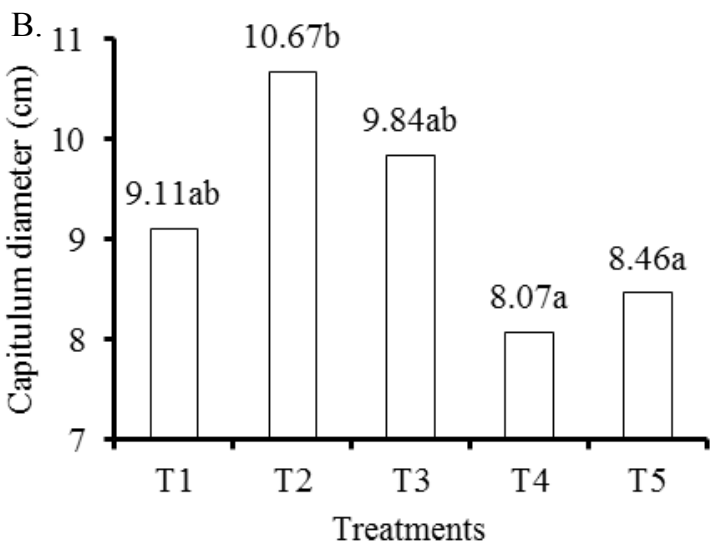

$\mathrm{T}_{1}=$ control with $100 \%$ water from the water supply (WWS); $\mathrm{T}_{2}=80 \% \mathrm{WWS}+20 \% \mathrm{LL} ; \mathrm{T}_{3}=60 \% \mathrm{WWS}+40 \%$ $\mathrm{LL} ; \mathrm{T} 4=40 \% \mathrm{WWS}+60 \% \mathrm{LL}\left(\mathrm{T}_{4}\right) ;$ and $\mathrm{T}_{5}=20 \% \mathrm{WWS}+80 \% \mathrm{LL}$. Means followed by at least one equal letter in the columns for each treatment do not differ at $5 \%$ probability by the Tukey's test.

Figure 5. Capitulum diameter (CD) of sunflower plants as a function of time of application of landfill leachate (LL) (A), and LL rates applied in the fertigation (B). 
Plants in the treatment with the lowest LL rate $(20 \%)\left(T_{2}\right)$ presented the largest mean $C D$ at the end of the crop cycle, but this treatment did not differ statistically from $\mathrm{T}_{1}$ and $\mathrm{T}_{3}$.

Similar to $\mathrm{PH}, \mathrm{NL}$ and $\mathrm{SD}$, the plants presented the lowest $\mathrm{CD}$ in $\mathrm{T}_{4}$ and $\mathrm{T}_{5}$, thus, the greater the LL rate applied to the soil, the lower the sunflower development.

This can be explained by the sodium applied to the soil with the LL. The high salt concentration in the leachate made the water unavailable to the crop, hindering its full development. In addition, the plant might have absorbed excess nutrients from the soil through phytoextraction. Sunflower crops have been widely studied by plant physiologists because of its high photosynthetic potential, high growth rates, high-water extraction and high-water conduction (MELLO et al., 2006).

The results found in the present study are in accordance with the ones found by Andrade et al. (2012), who reported that the use of wastewater improved significantly the sunflower plant height, number of leaves, stem diameter, and internal and external capitulum diameter. Moreover, Costa (2012) found maximum capitulum diameter of $7.06 \mathrm{~cm}$ using fertigation with $49 \%$ domestic wastewater.

\section{CONCLUSIONS}

The use of landfill leachate for fertigation of sunflower crops is a viable alternative for treatment and final disposal of this liquid residue. This practice can focus on the production of biofuel and vegetal biomass for energy purposes, reduce the erosion of soils that cover the solid urban waste, and save good-quality water resources.

The sunflower plant height, stem diameter, and capitulum diameter are affected by treatments with landfill leachate. The use of the treatment with $60 \%$ water from the water supply and $40 \%$ landfill leachate resulted in plants with better characteristics.

The application of high rates of landfill leachate in the soil decreases the sunflower quality and biomass production.

\section{ACKNOWLEDGEMENTS}

The authors thank the Federal Rural University of Semiarid (UFERSA) and the Environmental Sanitation Company (Sanepav) for the infrastructure, information, and part of the material used in this research.

\section{REFERENCES}

ALLEN, R. G. et al. Evapotranspiracíon del cultivo, Guías para la determinación de los requerimientos de agua de los cultivos. Roma: FAO, 2006. 298 p.

ALVARES, C. A. et al. Köppen's climate classification map for Brazil. Meteorologische Zeitschrift, Viena, v. 22, n. 6, p. 711-728, 2013.

ANDRADE FILHO, J. Cultivo da mamona utilizando percolado de aterro sanitário como fonte hídrica e nutricional. 2016. 112 f. Tese (Doutorado em Manejo de Solo e Água: linha de pesquisa Manejo de Solo e Água) - Universidade Federal Rural do Semi-Árido, Mossoró, 2016.

ANDRADE, L. O. et al. Qualidade de flores de girassóis ornamentais irrigados com águas residuária e de abastecimento. Idesia, Arica, v. 30, n. 2, p. 19 $27,2012$.

BEDIN, M. F. M. Avaliação da toxicidade do percolado proveniente de dois locais de disposição de resíduos sólidos urbanos, aterro de Passo Fundo e de Carazinho. 2011. 46 p. Monografia (Engenharia Ambiental: Área de Concentração em Engenharia Ambiental) - Universidade de Passo Fundo, Passo Fundo, 2011.

BONACIN, G. A. et al. Características morfofisiológicas de sementes e produção de girassol em função de boro no solo. Revista Brasileira de Engenharia Agrícola e Ambiental, Campina Grande, v. 13, n. 2, p. 111-116, 2009.

BRENTANO, D. M. Desenvolvimento e aplicação do teste de toxicidade crônica com Daphnia magna: avaliação de efluentes tratados de um aterro sanitário. 2006. 145 f. Dissertação (Mestrado em Engenharia Ambiental: linha de pesquisa Toxicologia Ambiental) - Universidade Federal de Santa Catarina, Florianópolis, 2006.

CALEGARI, A. et al. Caracterização das principais espécies de adubo verde. In: CALEGARI, A. et al. Adubação verde no sul do Brasil. 2. ed. Rio de Janeiro, RJ: AS-PTA, 1993. 344 p.

CÂMARA, G. M. S. Plantas Oleaginosas. 1. ed. Piracicaba, SP: ESALQ, 2003. 180 p.

CARRÃO-PANIZZI, M. C.; MANDARINO, J. M. G. Produtos Protéicos do girassol In: LEITE, R. M. V. B. C.; ALEXANDRE MAGNO BRIGHENTI, A. M.; CASTRO, C. (Eds.). Girassol no Brasil. Londrina: Embrapa Soja, 2005. cap. 4, p. 51-68.

CARVALHO, C. G. P. et al. Cultivar de girassol: BRS 324 - variedade com alto teor de óleo e precocidade. 1. ed. Londrina: Embrapa Soja, 2013. 2 
p. (Folder, n. 09).

CASTRO, C.; FARIAS, J. R. B. Ecofisiologia do Girassol. In: LEITE, R. M. V. B. C.; ALEXANDRE MAGNO BRIGHENTI, A. M.; CASTRO, C. (Eds.). Girassol no Brasil. Londrina: Embrapa Soja, 2005. cap. 9 , p. 163-218.

CASTRO, C. et al. A cultura do girassol. 1. ed. Londrina: Embrapa-CNPSo, 1997. 36 p. (Circular Técnica, 13).

CAVALCANTE JÚNIOR, E. G. Produção e necessidade hídrica da cultura do girassol irrigado na chapada do Apodi. 2011. $61 \mathrm{f}$. Dissertação (Mestrado em Irrigação e Drenagem: linha de pesquisa Necessidade Hídrica das Culturas e Manejo da Irrigação) - Universidade Federal Rural do Semi-Árido, Mossoró, 2011.

CHEVREMONT, A. C. et al. Impact of watering with UV-LED-treated wastewater on microbial and physico-chemical parameters of soil. Water Research, Londres, v. 47, n. 1, p. 1971-1982, 2013.

COSTA, F. G. B. Uso de água resíduária de origem doméstica no cultivo do girassol no assentamento Milagres. 2012. 92 f. Dissertação (Mestrado em Irrigação e Drenagem: linha de pesquisa Impactos da Irrigação e da Fertirrigação no Solo e na Planta) - Universidade Federal Rural do Semi-Árido, Mossoró, 2012.

DONAGEMA, G. K. et al. Manual de métodos de análise de solos. 2. ed. Rio de Janeiro, RJ: Embrapa Solos, 2011. 230 p.

DUTRA, I. C. B. Uso de água residuária de origem doméstica no cultivo da pimenta malagueta na região da Chapada do Apodi-RN. 2013. 69 f. Dissertação (Mestrado em Irrigação e Drenagem: linha de pesquisa Impactos da Irrigação e da Fertirrigação no Solo e na Planta) - Universidade Federal Rural do Semi-Árido, Mossoró, 2013.

EMPRESA BRASILEIRA DE PESQUISA AGROPECUÁRIA - EMBRAPA. Sistema Brasileiro de Classificação de Solos. 3. ed. Brasília, DF: Embrapa Solos, 2013. 353 p.

FERREIRA, A. L. L. Cultivo de oleaginosas em solos tratados com chorume de aterros sanitários. 2013. 69 f. Dissertação (Mestrado em Ciência do Solo: linha de pesquisa Impactos Ambientais pelo Uso do Solo e da Água) - Universidade Federal Rural do Semi-Árido, Mossoró, 2013.

FERREIRA, D. F. Sisvar: a computer statistical analysis system. Ciência e Agrotecnologia, Lavras, v. 35, n. 6, p. $1039-1042,2011$.
FERREIRA, D. F. Sisvar: a Guide for its Bootstrap procedures in multiple comparisons. Ciência e Agrotecnologia, Lavras, v. 38, n. 2, p. 109-112, 2014.

FREITAS, C. A. S. et al. Crescimento da cultura do girassol irrigado com diferentes tipos de água e adubação nitrogenada. Revista Brasileira de Engenharia Agrícola e Ambiental, Campina Grande, v. 16, n. 10, p. 1031-1039, 2012.

GAZZOLA, A. et al. A cultura do girassol. 1. ed. Piracicaba, SP: ESALQ, 2012.69 p.

HESPANHOL, I. Um novo paradigma para a gestão de recursos hídricos. Estudos Avançados, São Paulo, v. 22, n. 63, p. 131-158. 2008.

LAUERMANN, A. Caracterização química dos efluentes gerados pelo aterro controlado de Santa Maria e retenção de chumbo e zinco por um argissolo da depressão central do Rio Grande do Sul. 2007. 72 f. Dissertação (Mestrado em Ciência do Solo: Área de Concentração em Processos Físicos e Morfogenéticos do Solo) - Universidade Federal de Santa Maria, Santa Maria, 2007.

LIRA, M. A. et al. Avaliação das potencialidades da cultura do girassol, como alternativa de cultivo no semiárido nordestino. Natal: EMPARN, 2011. 40 p. (Documentos, 40).

LO MONACO, P. A. V. et al. Características químicas do solo após a fertirrrigação do cafeeiro com águas residuárias da lavagem e descascamento de seus frutos. Irriga, Botucatu, v. 14, n. 3, p. 348364,2009

LOPES, P. V. L. et al. Produtividade de genótipos de girassol em diferentes épocas de semeadura no oeste da Bahia. Pelotas: Embrapa Clima Temperado, 2009. 4 p. (Comunicado Técnico, 208)

MATOS, A. T. et al. Produtividade e composição química do capim-tifton 85 submetido a diferentes taxas de aplicação do percolado de resíduo sólido urbano. Engenharia Agrícola, Jaboticabal, v. 33, n. 1, p. 188-200, 2013.

MELLO, R. et al. Características fenológicas, produtivas e qualitativas de híbridos de girassol em diferentes épocas de semeadura para produção de silagem. Revista Brasileira de Zootecnia, Viçosa v. 35, n. 3, p. 672-682, 2006

MENDONÇA, J. M. S. Avaliação da ecotoxicidade de percolados em áreas de disposição de resíduos na região metropolitana de Natal/RN. 2010. $72 \mathrm{f}$ Dissertação (Mestrado em Ecologia: linha de pesquisa Ecossistemas Terrestres) - Universidade 
Federal do Rio Grande do Norte, Natal, 2010.

MESQUITA, F. O. Desempenho de gotejadores e produção de capim elefante Pennisetum purpureum Schum com percolado de aterro sanitário no semiárido. 2016. 149 f. Tese (Doutorado em Manejo de Solo e Água: linha de pesquisa Manejo de Solo e Água) - Universidade Federal Rural do Semi-Árido, Mossoró, 2016.

OLIVEIRA, M. F. et al. Melhoramento do Girassol. In: LEITE, R. M. V. B. C.; BRIGHENTI, A. M.; CASTRO, C. (Eds.). Girassol no Brasil. Londrina: EMBRAPA, 2005. v. 1, cap. 11, p. 269-297.

RICE, E. W.; BAIRD, R. B.; CLESCERI, A. D. Standard methods for the examination of water and wastewater. 22. ed. Washington: APHA, AWWA, WPCR, 2012. 1496 p.

SILVA, C. O. Avaliação do potencial de utilização de percolado bruto e tratado fotoeletroquimicamente de aterro sanitário no desenvolvimento da espécie Helianthus annuus $L$. 2014. 59 f. Trabalho de conclusão de curso (Bacharelado em Ciências Biológicas: Área de Concentração em Biotecnologia). Universidade Estadual Paulista, Instituto de Biociências de Rio Claro, Rio Claro, 2014.

SILVA, F. C. Manual de análises químicas de solos, plantas e fertilizantes. 2. ed. Brasília, DF: Embrapa Informação Tecnológica, 2009. 627 p.

SILVA, M. L. O. et al. Crescimento e produtividade do girassol cultivado na entressafra com diferentes lâminas de água. Revista Brasileira de Engenharia Agrícola e Ambiental, Campina Grande, v. 11, n. 5, p. $482-488,2007$.

SILVA, Y. G. F. et al. Qualidade de óleo de girrassol irrigado com esgoto doméstico tratado. Química: ciência, tecnologia e sociedade, Mossoró, v. 2, n. 2, p. 46-56, 2013.

SOUSA, J. R. M. et al. Germinação de sementes de girassol cv. BRS 324 submetidas a estresse salino simulado por $\mathrm{NaCl}$. Agropecuária Científica no Semiárido. Campina Grande, v. 8, n. 3, p. 123-127, 2012.

SOUZA, P. S. et al. Efeito de diferentes dosagens de $\mathrm{Fe}^{3+}$ na germinação do girassol. Revista Internacional de Ciências, Rio de Janeiro, v. 3, n. 2, p. 73-82, 2013. 